\title{
Foucault as Complexity Theorist: Overcoming the conundrums of classical philosophical analysis
}

\author{
Mark Olssen \\ University of Surrey
}

In my book Michel Foucault: Materialism and Education, ( original Bergin \&Garvey, 1999: chp. 11; paperback edition, Paradigm Press, 2006) I consider Foucault as a complexity theorist and relate him to contemporary conceptions of complexity as they are being utilised in the physical and social sciences. In order to set the background to a discussion of Foucault as complexity theorist it is necessary to consider briefly his both his appropriation of Nietzsche and his rejection of Marx in relation to the themes of chance and pluralism within his work.

Foucault's rejection of structuralism and Marxism, and his turn to genealogy and Nietzsche as the basis of his pluralistic conception became clearer at the close of the 1960s. With his growing interest in genealogy, Foucault became more concerned with power and history, and the historical constitution of knowledge. Although history was a process, it was a process that recognised no integrative principle or essence. If the genealogist studies history "he finds that there is 'something altogether different' behind things: not a timeless and essential secret, but the secret that they have no essence or that their essence was fabricated in a piecemeal fashion from alien forms" (Foucault, 1977a: 142

Foucault's conception of history explicitly reflects his Nietzschean heritage and his belief that certain aspects of Marxism and structuralism distorted the libertory potential of the discourse.

The interest in Nietzsche and Bataille was not a way of distancing ourselves from Marxism or communism - it was the only path towards what we expected from communism (Foucault, 2001: 249)

It was in terms of the philosophy of difference and Nietzsche's conception of multiplicities through a rejection of Platonic hierachies that Foucault enunciates a theory of discursive formations and rejects Marxist and 
Hegelian conceptions of history and establishes an approach with broadly parallels contemporary complexity theories. The utilisation of Nietzsche signalled a rupture from Marxism in relation to a series of inter-related conceptual, theoretical and methodological precepts, including power, knowledge and truth, the subject, and the nature of historical change and determination.

Nietzsche focussed on power in an altogether different way to Marx. In 'Prison Talk', Foucault (1980a: 47) states:

It was Nietzsche who specified the power relation as the general focus, shall we say, of philosophical discourse - whereas for Marx it was the productive relation. Nietzsche is the philosopher of power, a philosopher who managed to think of power without having to confine himself within a political theory in order to do so.

Power, for Nietzsche, was conceived as a relation of forces within an analytics of power/knowledge/truth, which became important for Foucault to understand in the later 1960s after the publication of The Archaeology of Knowledge and his growing friendship with the French Nietzschean Gilles Deleuze. Foucault accredits Nietzsche as the source of his interest in the question of truth and its relation to power. As he states, in 'Truth and Power' (Foucault, 1980: 133), “The political question...is not, error, illusion, alienated consciousness or ideology, it is truth itself. Hence, the importance of Nietzsche". Nietzsche's importance to Foucault can be seen as 'correcting Marx', especially in relation to the linkage between power-knowledge-truth, and the functioning of knowledge as an instrument of power. As Alan Schrift (1995: 40) notes, Nietzsche's influence drew attention away from "substances, subjects and things, and focussed attention instead on the relations between these substantives". In a related way, Foucault "draws our attention away from the substantive notion of power and directs our attention instead to the multifarious ways that power operates through the social order" (ibid). For Nietzsche, such relations were relations of forces. Foucault thus focussed on new relations as the relations of forces that existed and interacted within social systems as social practices. These were forces of repression and production that characterised the disciplinary society; forces that enable and block; subjugate and realise, and normalise and resist. In this model, power is not a thing, but a process, a relation of forces.

Beyond these concerns with power-truth-knowledge, and language and discourse, Foucault acknowledges the influence of Nietzsche in reference to the decentring of the subject, and the constitutive ethics of self-creation. In the Genealogy of Morals Nietzsche (1967) traces the processes of descent (Entstehung) and emergence (Herkunft), but distinguishes these from a concern with origins (Ursprung) or essences. Nietzsche's thesis is that 
the subject is historically constituted and does not exist as something given metaphysically in advance. This is what Nietzsche $(1967,1,13)$ means when he says “there is no 'being' behind doing, effecting, becoming; 'the doer' is merely the fiction added to the deed - the deed is everything". For Foucault, accepting this view of the subject, he sees it as an ideological product, an effect of power, whose identity is defined in relation to the functionality of discourse.

Nietzsche constitutes important background to understanding Foucault as a complexity theorist in relation to his critique of mechanical philosophy and his writings on causation, determinism and free will. In his book The Will to Power, which had a central influence on both Heidegger and Foucault, Nietzsche (1968: 339) attacks the mechanical physicalistic world view:

Physicists believe in a "true world" in their own fashion: a firm systematization of atoms in necessary motion, the same for all beings - so for them the "apparent world" is reduced to the side of universal and universally necessary being which is accessible to every being in its own way. But they are in error. The atom they posit is inferred according to the logic of perspectivism of consciousness - and is therefore itself a subjective fiction.

One way of interpreting the significance of such a statement from Foucault's perspective is to indicate the measure of his constructivism, or non-realism over concepts and categories of science. While Foucault subscribed to the view that sciences like physics clearly maintain parallels to the extractive powers of the universe, judged purely by the fruits of its efforts, such a science does not imply the actual existence of atoms or the workings of a mechanical system or a particular individualist representation of the world.

For Nietzsche, the Will to Power operates as a general metaphysic of which "life is merely one special case" (Nietzsche, 1968: 369). In Nietzsche's view, all being is becoming. As a method of critique it aims to expose illusion and falsehood. And on this basis Nietzsche criticizes the concepts of necessity and law, determinism and freedom. As he states (1968: 337):

Let us dismiss the two popular concepts "necessity" and "law": the former introduces a false constraint into the world, the latter a false freedom. Things do not behave regularly, according to a rule; there are no things (-they are factors invested by us); they behave just as little under the constraint of necessity. There is no obedience here: for that something is as it is, as strong or as weak, is not the consequence of an obedience or a rule or a compulsion -

Or, in even starker terms (1968: 297): 
From the fact that something ensues regularly and ensues calculably, it does not follow that it ensues necessarily. That a quantum of force determines and conducts itself in every particular case in one way and manner does not make it into an "unfree will". "Mechanical necessity" is not a fact.

In his rejection of mechanical philosophy and organicism Nietzsche asserts a radical ontology whereby the conception of the totality or whole is reconfigured as an always open, relatively borderless system of infinite interconnections, possibilities and developments. Nietzsche's "fundamental metaphysical position", as Heidegger (1984: II, chap. 12) reminds us, posits a philosophical ontology that while it comprises a semiotic system of finite particulars, it is nevertheless a system which is open-ended and contains infinite possibilities for reinvestment. The conception of an infinite relational order liberates conceptions of the whole from the traditional finitude associated with Hegel. This can be seen as an opening towards a non-linear system of dynamics and change. In relation to a politics of space, the conception of the community becomes reconfigured as an open borderless arena where changes are instrumented both internally and externally as elements within and without themselves undergo change. This applies to any system, including language, and can be represented in relation to the economy of the metaphor. In the words of David B. Allison (1977, p xvi):

...metaphorical signification amounts to a chain of substitutions.... While the number of possible substitutions...is finite, i.e., is bounded by resources of a given language - the process of substituting one for another is open-ended. The constitution of the metaphor is thus a process that is at least temporality open to infinity. The metaphor, then, enjoys a "finite" but "open" economy.

This finite but open economy of signification also works, says Nietzsche in relation to the will to power. While the field of forces is finite, it can be continually expended and recombined. Allison (p. xvii) cites Nietzsche from s639 of The Will to Power:

Regarded mechanistically, the energy of the totality of becoming remains constant; regarded economically; it rises to a high point and sinks down again in an eternal circle. This "Will to Power" expresses itself in the interpretation, in the manner in which force is used up.

In his own representation, Heidegger (1991, Vol. II, Chap. 12) summarizes the "Presentation and grounding" of Nietzsche's doctrine with regards to "Being as a whole as Life and Force", and "the World as Chaos".

Heidegger lists several core theses which are central to Nietzsche's world view:

(1) Force is the pervasive character of the world? Force, for Nietzsche, is the will to power (Vol. II, p. 86). 
(2) Force is limited, because it is finite. "In itself" force is "determinate" and "inherently limited" (Vol. II, p. 87). "Because force, which is essentially finite, is the essence of the world, the totality of the world itself remains finite" (Vol. II, p. 88). Hence there is a "firm confinement within boundaries" (Vol. II, p. 88).

(3) "The lack of diminuation and accretion in universal force signifies not a 'standstill'...but a perpetual 'Becoming'. There is no equilibrium of force. Heidegger continues, "We must grasp 'Becoming' here quite generally in the sense of transformation or - still more cautiously - change.” (Vol. II, p. 88).

(4) "Precisely because the world is perpetual Becoming, and because as a totality of force it is nonetheless inherently finite, it produces "infinite" effects". Nietzsche uses the phrase "infinitely waxing" to describe force in relation to its potentials (Vol. II, p. 87).

(5) "In contrast to the imaginary character of space, time is actual” (Vol. II, p. 90) Furthermore, "It is also - in contrast to the bounded character of space - unbounded, infinite". He quotes Nietzsche from The Gay Science (S. 341), where he speaks of "the eternal hourglass of existence”. For Heidegger (Vol. II, p. 90), "Such actual, infinite time, Nietzsche grasps as eternity"

(6) Heidegger (vol. II, p. 91) cites Nietzsche from The Gay Science (s109): "The collective character of the world is...to all eternity - chaos" - and this is "the fundamental representation of being as a whole" (Heidegger, Vol. II, p. 91). This representation, as Nietzsche notes (s109), chaos applies not in the sense of a "lack of necessity, but a lack of order" (Heidegger 1991, Vol. II, p. 90). Hence, the world lacks order or lawfulness, as well as predictability.

(7) The idea that beings proceed according to 'laws' is a "humanization", or "moralistic-juridical mode of thought", says Heidegger (Vol. II, p. 92). It is "anthropomorphic". He continues: "Nor are there in beings any 'goals' or 'purposes' or 'intentions'; and if there are no purposes, then 'purposelessness' and 'accident' as well are excluded" (Vol. II, p. 92). Just as mechanics is wanting, so too is the idea of the universe as an "organism". Such a notion is for Nietzsche just a further "humanization", says Heidegger (Vol. II, p. 93).

Heidegger draws his summary of Nietzsche's position largely from The Gay Science and The Will to Power. But most of Nietzsche's texts from the 1880s until his death could be drawn upon for support. With Nietzsche, then, 
we have an ontological position which stresses "force, finitude, perpetual Becoming, the innumerability of appearances, the bounded character of space, and the infinity of time" (Vol. II, p. 90-91). And these relate back to the collective character of the world. While as Heidegger (Vol. II, pp. 91-92) notes, "although Nietzsche distinguishes the concept of the world from the notion of fortuitous and arbitrary jumble, a sort of universal cosmic porridge, he nevertheless fails to liberate himself from the transmitted sense of chaos as something that lacks order and lawfulness". Such are the labyrinths of Nietzsche's thought.

That Foucault agrees with the broad philosophical ontology of Nietzsche's approach has influenced his own epistemological constructivism, social constructionism, as well as the theory of social forces and power, is now well-known. In general terms, Nietzsche's constructivism and his belief in chance were to become hallmarks of Foucault's own approach. The view of history as pluralist and not accounted for within a context of causal, 'iron-law' determinism was thus important in Foucault's debt to Nietzsche, and also contributes background to understanding the affinities with complexity theory. Whereas Marxists like Althusser adopted a totalistic programme of seeking to explain the whole by understanding the interrelations between its component parts, for Foucault the totality always eluded analysis or understanding in terms of structure, but rather was characterised by incompleteness, indeterminacy, complexity and chance. This was the core of his pluralism. As Foucault says, "though it is true that these discontinuous discursive series each have within certain limits, their regularity, it is undoubtedly no longer possible to establish links of mechanical causality, or of ideal necessity between the elements which constitute them. We must accept the introduction of alea (chance) as a category in the production of events" (Foucault, 1981: 69) ${ }^{1}$.

In seeking to characterise the nature of his 'pluralism' and how it effects the analysis of discourse as operating through complex laws, Foucault (1978: 11) explains how he "substitutes the analysis of different types of transformation for the abstract, general, and monotonous form of 'change' in which one so willingly thinks in terms of succession". In this, he seeks to define with the greatest care the transformations which have constituted the change, replacing the general theme of becoming ("general form, abstract element, primary cause, and universal effect") by the analysis of the transformations in their specificity, an examination of "the diversity of systems and the play of discontinuities into the history of discourse" (1978: 15). This involves, says Foucault (1978: 11-12), within a given discursive formation (1) detecting the changes which effect the operations, objects, theoretical choices, etc.; (2) detecting the changes which effect the discursive formations themselves (e.g. changes in the boundaries that define the field); (3) changes which effect simultaneously 
several discursive formations (e.g. reversal of the hierarchy of importance, as happened, for instance, in the Classical period when the analysis of language lost the 'directing role' that it had in the first years of the nineteenth century to biology, which in turn lead to the development of new concepts such as 'organism', 'function', 'organisation' etc., which in turn effected other sciences). All of these types of changes, says Foucault, characterise changes to both individual discourses and effect modifications in the episteme itself: its "redistributions", i.e. "the different transformations which it is possible to describe concerning ... states of a discourse". In opposition to totalising models Foucault sees his own analysis as more limited: to searching for the empirical historical grounds for discursive consistency or coherence; to recognising in discourse its empirical worldly features--"the work of the author. And why not? --His juvenilia or mature work, the patterns of a linguistic or rhetorical model (an idea, a theme)"; and acknowledging that the transformatory operations are all carried out "prior to discourse and outside of it" (1978: 17).

In his later reflections on method, in response to interviews on the subject of Discipline and Punish, Foucault (1987) asserts the 'pluralist' nature of his project through his use of concepts like 'eventalization'; that 'specific events' (événements signuliers) cannot be integrated or decoded simply as an application of a uniform and universal regularity. In this non-unified sense, the analytic of discourse effects a non-unified method. As Foucault (1972: 8) explains it:

It has led to the individualization of different series, which are juxtaposed to one another, follow one another, overlap and intersect, without one being able to reduce them to a linear schema. Thus, in place of the continuous chronology of reason, which was invariably traced back to some inaccessible origin, there have appeared scales that are sometimes very brief, distinct from one another, irreducible to a single law, scales that bear a type of history peculiar to each one, and which cannot be reduced to the general model of a consciousness that acquires, progresses, and remembers.

The notion of 'eventalization' itself contains a number of elements. First it treats all objects of knowledge as historical events. Second, it refers to a "pluralization of causes" (Foucault, 1987: 104105):

Causal multiplication consists in analysing an event according to the multiple processes that constitute it. . . "[E]ventalization" thus works by constructing around the singular event analysed as process a "polygon" or rather a "polyhedron" of intelligibility, the number of whose faces is not given in advance and can never properly be taken as finite. One has to proceed by progressive, necessarily incomplete saturation. And one has to bear in mind that the further one decomposes the processes under analysis, the more one is enabled, and indeed obliged to construct their external relations of intelligibility. 
In addition, says Foucault (1987: 104) eventalization refers to the rediscovery of the "connections, encounters, blockages, plays of forces, strategies, etc. that at a given moment establish what consequently comes to count as being self evident, universal and necessary". In this sense, it constitutes a "breach of self evidence", i.e.:

It means making visible a singularity at places where there is a temptation to invoke historical constants, an immediate anthropological trait, or an obviousness that imposes itself uniformly on all. To show that things 'weren't as necessary as all that; that it wasn't a matter of course that mad people came to be regarded as mentally ill; it wasn't self-evident that the only things to be done to a criminal were to lock him up, it wasn't self-evident that the causes of illness were to be sought through the individual examination of bodies; and so on.

In this sense, eventalization opposes the evidences upon which knowledge sequences and practices rest. Its theoretical quest is endlessly open. It operates in Foucault's (1987: 105) view, "as a procedure for lightening the weight of causality".

Alongside the concept of eventalization are those of exteriority/interiority, which Foucault (1972: 120-122, 125, 140) discusses in The Archaeology of Knowledge as well as in his inaugural lecture at the College de France (see Foucault, 1981), as well as in his essay on Blanchot (Foucault, 1990). What Foucault means by 'exteriority' is that the being of discourse resides in the "pure dispersion" of the socio-historical processes of reproduction and change; in the "particular events, regularities, relationships, modifications and systematic transformations", which constitute an "autonomous (although dependent)" domain, and "which can be described at its own level" (1972: 121-2). As expressed in his essay on Blanchot (1990: 15), it is "the breakthrough to a language from which the subject is excluded...the being of language only appears for itself with the disappearance of the subject". This places the emphasis on 'speech' rather than on the Cartesian Cogito. As he states (1990: 13):

\footnotetext{
"I speak" runs counter to "I think". "I think" led to the indubitable certainty of the "I" and its existence; "I speak", on the other hand, distances, disperses, effaces that existence and lets only its empty emplacement appear. Thought about thought, an entire tradition wider than philosophy, has taught us that thought leads us to the deepest interiority. Speech about speech leads us, by way of literature as well as perhaps by other paths, to the outside in which the speaking subject disappears. No doubt that is why Western thought took so long to think the being of language: as if it had a premonition of the danger that the naked experience of language poses for the self-evidence of the "I think".
}

Manfred Frank emphasises the ontological and methodological functions of exteriority. What Foucault means by exteriority, he says (1992: 108) is that each individual element in discourse is irreducible "to the unified discursive principle, or to an internal core of meaning to be found in the discourse". As he continues: 
What the rule of exteriority of discourse means then, is: `not moving from the discourse towards its internal, hidden core, towards the heart of the thought or the meaning, which is manifest in it'. So the procedure of the analytic of discourse is external because it wishes to leave the series (série) of single events, mutually irreducible (in terms of a deductive or teleological principle), just as they are 'external' to any totalizing general concept.

In a methodological sense, in that events and instances are individualized, 'individualized' means here, as Frank (1992: 110) states it, "not predictable from the point of view of their structure, and contingent with respect to the way they happen to be". What is important in terms of the analytics of discourse is not seeking such a reduction: hense the analytics of discourse is external to the process of analysis. What is important to Foucault (1990: 1516) is that:

thought stands outside subjectivity, setting its limits as though from without, articulating its end, making is dispersion shine forth, taking only its invincible absence; and that at the same time stands at the threshold of all positivity, not in order to grasp its foundation or justification but in order to regain the space of its unfolding, the void serving as its site, the distance in which it is constituted and into which its immediate certainties slip the moment they are glimpsed - a thought that, in relation to the interiority of our philosophical reflection and the positivity of our knowledge, constitutes what in a word we might call "the thought from the outside".

As well as referring to consciousness, interiority thus refers also to any foundation or centre to the social formation which the events or parts echo or reflect. Hence, again, this can also be seen as consistent with, and expressing, his opposition to the notion of a determined causality embodied in the Hegelian conception of an "expressive totality" and, by derivation, also embodied in the notion of a primary causal necessity (un causalisme primaire) which he sees as central to Marxism. In this sense, the analytics of discourse must resist interiorization, "forsaking the wordy interiority of consciousness", as well appeal to a centre or foundation, and become, as in Bataille, the "discourse of the limit" (1990: 18).

What Foucault, following Nietzsche, Blanchot and Bataille, also elaborates as a theme, is the "uniqueness" and "unpredictability" of the singular historical instance, and it is this that I will claim below enables us to forge links between Foucault and complexity theory. What he seeks to do is introduce conceptions of indeterminacy, irregularity, openness, complexity, and uniqueness as integral to his conception of the historical process. This means that any event contains an element of uniqueness. In The Archaeology of Knowledge (1972: 101) examples abound: it takes the form of establishing the spatio-temporal co-ordinates that ensure the novel aspect of the `statement' (énoncé): "The enunciation is an unrepeatable event; it has situated and dated uniqueness that is irreducible. Yet this uniqueness allows of a number of constants--grammatical, semantic, logical--by which we can, by neutralising the moment of enunciation and the co-ordinates that individuate it, recognise the general 
form". Or again (1972: 146-7), "every statement belongs to a certain regularity--that consequently none can be regarded as pure creation, as the marvellous disorder of genius. But we have also seen that no statement can be regarded as inactive, and be valid as the scarcely real shadow or transfer of the initial statement. The whole enunciative field is both regular and alerted: it never sleeps". This fact that the future never simply reproduces the past, but adds always elements of novelty, means that the self is never simply the reproduced habitus of its socialisation, but due to its necessarily distinct location in time and space and culture, as well as its progressively growing capacity for agency, is characterised by elements of difference and uniqueness. Yet this difference and uniqueness is not an artefact of language but a real phenomenon. In addition, it means that ethical values can never simply be expressed merely as repeatable rules of conduct, which increases, rather than decreases, our sense of ethical responsibility in action.

Such a conception also expresses an 'internalist' view of history which is central to underpinning how Foucault understands change and how issues like freedom and determinism are resolved. Such a view of history means that there is no guiding principle underlying structures or their emergence. Difference then is historical, and resists both the univocity of being, as well as transcendence in all its forms, whether God, Cogito, Forms, Economy. There is nothing outside of history. Although such a conception does not adopt a uniform ahistorical model of temporalisation, or prioritise one element (economy) over others, neither does it deny that invariant necessities may exist which can express themselves through the different discursive lens of a particular historical periods. In this sense, as Joseph Margolis (1993: 204) notes, Foucault does not deny a world of 'things', he:

\begin{abstract}
does not dismiss de re necessities of this or that episteme; they are rightly recognised there as the necessities they are. But they are also not enshrined as universal, changeless structures of any kind (regarding world or reason). [Rather] we are always invited to "test" for the "limits" that we may go beyond. That's to say: the invariances of any proposed transcendental limits of reason may be tested by exploring whether we can alter such a model of coherence convincingly, in a way that rests on historical change.
\end{abstract}

Similarly, such a conception can be claimed to resist the charge of epistemological relativism. As Foucault (1984a: 335) puts it in the Preface to the History of Sexuality, Volume II, he says that he is not denying the possibility of universal structures:

Singular forms of experience may perfectly well harbor universal structures: they may well not be independent from the concrete determination of social existence...(t)his thought has a historicity which is proper to it. That it should have this historicity does not mean that it is deprived of all universal form but instead the putting into play of these universal forms is itself historical. 
Like Heidegger, in Being and Time, Foucault manifests a pragmatic anti-foundationalism. Such an approach bares a similarity to parallel developments in Western Anglo-American philosophy to writers like Dewey, Quine, Davidson, Putnam, Kuhn, and Goodman, and in the continental tradition to writers like Habermas, Bourdieu and Apel. While all developed versions of historicism, all denied any total pernicious form of relativism and all claimed a measure of objectivity. For Foucault, the maxim that 'everything is historical' means that while we remain forever imprisoned by contingency, non-correspondence, relativity and ideological prejudice, there are some 'footholds', even if they do not lead easily to a uniform consensus. Foucault's antiessentialism places him alongside a possible (pragmatic) reading of Popper, who also rejected essentialist ontologies, in that there is nothing that prevents testing and attempted falsifications in order to 'take a bearing', or 'check the situation out'. While this will give a certain form of confidence on some issues, on others, the conditions of what constitutes falsifiability will not be so easy to foresee ${ }^{2}$. Foucault's realism holds to the view that correspondence or synchronization of discourse and reality is not required. Rather than correspondence, we must speak of isomorphism. There is no assurance, pace Kant, either, of transcendentally valid and universally reliable cognitive schemata, for such a conception relies on a conception of a subject posited prior to history. What justified Kant's cognitive schemata depends on various historically contingent conditions within what Heidegger would call the 'horizon' within which they appear. This doesn't mean there are no historical justifications (survival), nor does it mean there are no footholds of any sort. But with Heidegger, Foucault's thesis of the historicity of existence would deny that there is any eternal 'point of view'.

Although Foucault acknowledges a debt to Nietzsche, it would be an error to represent his approach as simply Nietzschean, and would misrepresent his relation to Marx and to radical politics. As well as Nietzsche, Foucault has debts to Heidegger, and Herbert Dreyfus (1992: 80-81) claims that "it was through Heidegger that Foucault came to appreciate Nietzsche". As Foucault (1985: 9) says: “it is possible that if I had not read Heidegger, I would not have read Nietzsche. I had tried to read Nietzsche in the fifties but Nietzsche alone did not appeal to me - whereas Nietzsche and Heidegger, that was a philosophical shock". Ultimately, Foucault "nevertheless recognised that Nietzsche outweighed [Heidegger]". But both exacted an influence. One of the central themes which Foucault shared with Heidegger and Nietzsche, as well as with the French Marxist, Althusser, was their challenge to the Cartesian and Kantian conceptions of the subject. He was also influenced by Heidegger in terms of the understanding of Being as indicating the presuppositions, things, tools, language, institutions, shared understandings, and other people which determines what is deemed possible or impossible, or what counts as important or unimportant, or meaningful or unmeaningful. Like Heidegger, Foucault came to reject 
the view of a constant, ahistorical, universal truth, which came to influence his rejection of essentialism and other forms of foundationalism, thereby influencing the precise nature of his materialism. Yet another writer that Foucault has course to refer to is Spinoza, whom he refers to and summarises in several of his papers over the course of his writing career ${ }^{3}$. While Spinoza cannot be represented as a direct influence, and one must be cautious about attribution of themes or concepts, Foucault's detailed understanding of Spinoza is suggestive in that Spinoza's concepts of power, politics, of collective and individual praxis, and of republican constitutionalism, and general theme of complexity can, if suitably modified according to the dictates of difference, be rendered broadly compatible with Foucault's approach ${ }^{4}$.

\section{Complexity and openness}

In that Foucault talks of 'chance' and 'unpredictability', such a conception of historical openness is not technically incompatible with deterministic Newtonian physics, in the sense that events and outcomes are still the result of antecedent conditions. Foucault, however, follows Nietzsche who introduced indeterminancy into the Newtonian theory. Rather than postulate a closed universe with a small number of invariable, universal laws which could explain everything, and predict the future, the universe is theorised an infinitely open, complex whole, characterised by unpredictability, uncertainty and change. Causation in Foucault's view is conceived of systemically, in terms of a model of holism-particularism, or complex causation, which makes events, which are the outcomes of system interactions in open systems, effectively unpredictable, in that the full range of possible combinations or effects cannot be specified in advance. Complex systems, moreover, are contingent and dynamic, whereby the structure of the system is continuously transformed through the interaction of the elements and which are not explainable in reference to any external principle, origin, or foundation. In this process, says Cilliers (1998: 107-108), "no complex system, whether biological or social, can be understood without considering its history....To be more precise, the history of a system...co-determines the structure of a system". In this theory, while change is understood as the outcome of contingent complex activity, human agency is understood as an emergent property of the historical and social system ${ }^{5}$.

In insisting on the open nature of the historical system, Foucault's approach to understanding history parallels Derrida's critique and revision of Saussure in stressing the open and incomplete character of the totality of social relations. In Foucault, however, the analysis proceeds beyond the textual to an analysis of the historical relations between the discursive and pre-discursive, whereas for Derrida and Saussure the analysis is synchronic and confined to language. Throughout his career, in fact, it can be said that Foucault maintains a distinction 12 
between the discursive and the pre-discursive. In his early period, prior to the Archaeology of Knowledge, written in 1968, Foucault sees discourses formed on the basis of epistemes that provide a unified view of intellectual life during a particular period or age. After his turn to genealogy, he developed such an approach more directly in relation to how the practices discursive and pre-discursive were related. As a consequence, in retaining the post-structural emphasis on the open and incomplete nature of the totality, but applied to history and social relations, rather than language, Foucault's more materialist approach has radical implications for our understanding of concepts like determinism, predictability, and the future.

In this context, it is worth noting the parallel between Foucault's systemic conception of change, linked closely to a system of open possibilities or variations, and what is now known as complexity theory. Although having roots in ancient Chinese and Greek thought, versions of complexity theory are a relatively new field of scientific enquiry, and are perhaps one of the most notable new developments since the advent of quantum theory in the early 1900s. Such theories are not only compatible with materialism, but are systemic, or holist, in that they account for diversity and unity in the context of a systemic field of complex interactional changes. Chaos theory is one version of complexity. Partly with origins in computing technology, and partly in the development of new non-Euclidean structures of fractal geometrical mathematics, chaos theory became concerned to explain "the qualitative study of unstable aperiodic behaviour in deterministic non-linear dynamical systems" (Sardar and Abrams, 1999: 9) ${ }^{6}$. It is complexity theory more broadly, however, that has drawn off post-structural methods, and establishes them as a form of critical realism ${ }^{7}$.

In the recent history of science, the work of Ilya Prigogine $(1980,1984,1989,1994,1997,2003)$ has advanced the field of post-Quantum complexity analysis at the macroscopic and microscopic levels, based in nonequilibrium physics, linked to the significant work of the Solvay Institutes for Physics and Chemistry. Prigogine received a Nobel Prize in 1977. Like Nietzsche and others before him, he translated the effects of a theory of becoming, based on an Heraclitean idea of ceaseless change, providing a post-Quantum understanding of the universe in terms of dimensions of chance, unpredictability, uncertainty, chaos, non-equilibrium systems, and change. Prigogine's central contribution was to non-equilibrium statistical mechanics and thermodynamics and the probabilistic analysis of complex systems $(2003: 45,82)$. His main ideas (expressed nonmathematically) were that "nature leads to unexpected complexity" (2003: 8); that "self-organization appears in nature far from equilibrium" (p. vii); that "the universe is evolving" (p. 9); that the messages of Parmenides (that nothing changes) must be replaced by those of Heraclitus (that everything always changes) (p. 9, 56); that "time 
is our existential dimension" (p. 9); that "time is an invention" (p. 10); that "the direction of time is the most fundamental property of the universe" (p. 64); that nothing is predetermined (p. 9); that non-equilibrium, timeirreversibility, and non-integration, are features of all systems, including evolution, which is to say that our universe is full of nonlinear, irreversible processes (p. 59); that life creates evolution (p. 61, 65), and that everything is historical (p. 64) ${ }^{8}$.

In his book Complexity and Postmodernism, Paul Cilliers (1998: viii) defines complexity in the following way:

In a complex system...the interaction constituents of the system, and the interaction between the system and its environment, are of such a nature that the system as a whole cannot be fully understood simply by analysing its components. Moreover, these relationships are not fixed, but shift and change, often as a result of self-organisation. This can result in novel features, usually referred to in terms of emergent properties. The brain, natural language and social systems are complex.

Poststructuralism, says Cilliers, has introduced a new conception of complexity based on 'distributed' or 'relational' representation, following Saussure' ${ }^{9}$ Such a system is complex in relation to the fact that it has a large number of elements which interact dynamically in a non-linear and asymmetrical manner. Interactions take place in open systems through 'self-organisation' by adapting dynamically to changes in both the environment and the system. Self-organisation is an emergent property of the system as a whole. An emergent property is a property that is constituted due to the combination of elements in the system as a whole. As such it is a property possessed by the system but not by its components ${ }^{10}$. Cilliers (1998: 90) defines 'self-organisation' as "the capacity of complex systems which enables them to develop or change internal structure spontaneously and adaptively in order to cope with or manipulate the environment". Such systems are not in equilibrium because constantly changing as a consequence of interaction between system and environment, and as well as being influenced by external factors are influenced by the history of the system (1998: 66). Cilliers identifies social systems, the economy, the human brain, and language as complex systems ${ }^{11}$.

Hence one could characterise Foucault's conception of societies as 'non-equilibrium systems', where no general laws can predict the detailed behaviour of such systems. As much that develops does so as a consequence of emergence, life is created as a consequence of the collective interactions of parts. This entails not only the limitless possibility of combinations that can occur in open environments, but also that as the collectivity possesses properties and energies not possessed by the parts, but through which change can take place, new forms and patterns can develop. Relatively small changes in initial conditions can trigger major changes throughout the system, in part or whole. Such a perspective gives a new insight to the 'contradictions of capitalism $^{12}$. Although for Foucault, the economy can not be represented as a transhistorical foundation 
permitting an understanding of change in history, it can be analysed internally, i.e., a genealogy of capitalism in terms of the history of economic structures, and the effects they engender throughout the social structure.

Although I realise that this brief account can not possibly do justice to the topics of complexity theory, emergence, chance or critical realism, it is broadly in this direction that Foucauult's historical materialism leads.

\title{
The nature of identity
}

Such a notion of Foucault as complexity theorist also enables us to understand his views towards identity, as well as many other philosophical conundrums. Let me start with identity. Given that structural linguistics seeks to define identity relationally, Saussure (1974: 120) argued that it can not posit a theory of identity as a substantive entity, or as a concrete 'positive' unique particularity. This was retained by Derrida in his revision of Saussure's view, seeing identities as constituted by the series of traces of the differences in the system ${ }^{13}$. But if one conceives of identity in purely relational terms, as Mark Currie (2004: 13) notes, "it could be said that the concept of difference is no respector of difference". As he continues, in explaining Saussure's view:

\begin{abstract}
A theory of subjectivity, or personhood, for example, might locate identity not in the body of the individual but in the relations between that person and others. In other words a person might not be defined by inherent characteristics, but like Saussure's train or chess piece, be understood as an identity only because of the relationships that person has with other people, in a system of family, friendship and social relations. This would be referred to as a relational view of personal identity. The same might be said of collective identities. It might be argued for example, that a national identity is not one that is made up of inherent qualities (of 'positive terms' in Saussure's language) but of relational ones concerned with how a nation distinguishes itself from other nations.
\end{abstract}

For Nietzsche, Deleuze and Foucault, difference operates historically and has a dynamic quality that the theories of Saussure and Derrida lack. On this basis there is no reason why the traces that infuse identity could not be seen as leaving a residue or mark, developing into a positive conception of self constituted through complex interactions in the to and from of the historical process. The stress on historical praxis creates a more enduring sense of identity in this sense. While this still leaves identity as relational in terms of its constitution, an identity which can be represented as positive and substantial (in the sense of it being irrepressible or non-reducible) is the outcome of self-creation or constitutive praxis in history ${ }^{14}$.

Such a view has the advantage over Saussure's and Derrida's view in that it can account for a substantial conception of the self, and explain, in the context of historical and social contructionist views of the self, how identities can emerge that are both distinct and unique ${ }^{15}$, which are non-reversible, and irreducible to the social whole $^{16}$. For Nietzsche and Deleuze, following Duns Scotus, Spinoza, and Hume, identities are constituted in 
experience, which is defined in terms of complex effects and relations, as practices (or for Deleuze, haecceities) whose complex modes of operation are individuating (but not personalising or privatising). For Deleuze (1985, 1987: chp. 1), such patterns show parallels to nomadology or rhizomatic (rather than arborescent) development. For Foucault (1990), it is "outside thought"; for Nietzsche, "gay science”. In twentieth century Marxist thought, Althusser's conception of structural causality, as outlined at the start of this paper, partly fits such a model ${ }^{17}$. Similar models of organisation and development are also evident in Spinoza's "ethics", as what Spinozian interpreters like Damasio (2003: 37) call “nesting” theories of development, where the "parts of simple reactions [are] incorporated as components of more elaborate ones, a nesting of the simple within the complex"18. Yet other approaches utilizing complex models, although in somewhat variable ways, are cybernetics, or the early theories of Gregory Bateson (see Bateson, 1972).

\section{Holism-particularism, uniqueness and creativity}

We can see how Foucault's general method enables uniqueness to emerge from antecedent conditions. I have described his method elsewhere as one of 'holism-particularism' (Olssen, 1999: chp. 11). Foucault (1994b: 824-5) himself talks about his own method in Dits et Écrits as a "logical analysis of reality", and distinguishes it from "the determinist ascription of causality" in Marx, as well as "the logic of the Hegelian type". Arnold Davidson (1997: 11) in a review of Dits et Écrits to which my own analysis is indebted, characterizes Foucault's methodological strategy in terms of a "non-reductive" and "holistic" analysis of social life. As he puts it (Davidson, 1997: 11):

This kind of analysis is characterized, first, by anti-atomism, by the idea that we should not analyze single or individual elements in isolation but that one must look at the systematic relations amongst elements; second it is characterized by the idea that the relations between elements are coherent and transformable, that is, that the elements form a structure.

Thus, in his dissertation on the knowledge of heredity as a system of thought, submitted as part of his application for his position at the Collège de France, Foucault seeks to describe the changes, transformations, and conditions of possibility that made genetics possible, that constituted it as a science based on a series of discourses concerning breeding, just as in The Order of Things (1970) he had done for natural history and biology. What factors led to the emergence of these fields as sciences? What elements changed to make such developments possible? What made them possible as systems of thought? Thus Foucault seeks to describe the relations among elements as structures which change as the component elements change, in an always open system where unexpected outcomes and novel features are contingent inevitabilities of the process of history. 
Such an approach make it possible to explain how individuals are on the one hand the outcome of social and historical processes and yet how on the other hand novelty, uniqueness and creativity are possible. By interpreting Foucault in such a light, we can begin to make sense of his comments and general sense of incredulity in response to questions that were put to him on the general dimension of 'social construction/individuation'. As he says in The Archaeology of Knowledge (1972: 200):

If I suspended all reference to the speaking subject, it was not to discover laws of construction or forms that could be applied in the same way by all speaking subjects, nor was it to give voice to the great universal discourse that is common to all men at a particular period. On the contrary, my aim was to show what the differences consisted of, how it was possible for men, within the same discursive practice, to speak of different objects, to have contrary opinions ... in short I want not to exclude the problem of the subject but to define positions and functions that the subject could occupy in the diversity of discourse.

It is not unrelated to his general conception of complexity that Foucault also seems to suggest the genuine possibility of free agency and creativity. With reference to thought, for instance, he describes it as an original and creative response in relation to social determinants. As Foucault (1984b: 388-389) puts it:

For a domain of action, a behaviour, to enter the field of thought, it is necessary to have made it lose its familiarity, or to have provoked a certain number of difficulties around it. These elements result from social, economic, or political processes. But here their only role is that of castigation. They can exist and perform their action for a very long time, before there is effective problematization by thought. And when thought intervenes, it doesn't assume a unique form that is the direct result or the necessary expression of these difficulties; it is an original or specific response--often taking many forms, sometimes even contradictory in its different aspects--to these difficulties, which are defined for it by a situation or a context and which hold true as a possible question.

Thought, then, arises as a unique event from a context of rules. Hence, it is always the case, says Foucault (1984b: 389) that:

to a single set of difficulties, several responses can be made ... But what has to be understood is what makes them simultaneously possible: it is the point in which their simultaneity is rooted; it is the soil that can flourish them all in their diversity and sometimes in spite of their contradictions.

A similar line or reasoning, dissecting the general from the particular, and the social from the individual, is evident in his debate with Chomsky (Foucault and Chomsky, 1997: 119-120) where he refers to "free creation within a system of rules":

One can only, in terms of language or of knowledge, produce something new by putting into play a certain number of rules. . . . Thus we can roughly say that linguists before $\mathrm{Mr}$ Chomsky mainly insisted on the rules of construction of statements and less on the 
innovation represented by every new statement. ... And in the history of science or in the history of thought, we place more emphasis on individual creation, and we had kept aside and left in the shadows these communal general rules, which obscurely manifest themselves through every scientific discovery, every scientific invention, and even every philosophical innovation.

In this sense, Foucault explains the originality and uniqueness of the subject in the same way, and using the same arguments as he explains the originality of statements (énoncés). In the interview with Chomsky, Foucault agrees that "rules and freedom are not opposed to each other". In fact, the point he is at pains to stress in the interview with Chomsky is that within any system of rules, in the long run "what is striking is the proliferation of possibilities by divergences" (p. 122). As he says (p. 123):

$[C]$ reativity is possible in putting into play a system of rules; it is not a mixture of order and freedom ... . where I don't completely agree with Mr Chomsky is when he places the principle of these regularities, in a way, in which the interior of the mind or of human nature. . . If it is a matter of whether these rules are effectively put to work by the human mind, all right; all right, too, if it is a question of whether the historian and the linguist can think it in their turn; it is all right also to say that these rules should allow us to realise what is said or thought by these individuals. But to say that these regularities are connected, as conditions of existence, to the human mind or its nature, is difficult for me to accept; it seems to me that one must, before reaching that point . . . replace it in the field of other human practices, such as economics, technology, politics, sociology, which can serve them as conditions of formation, of models, of place, or apparition, etc. I would like to know whether one cannot discover the system of regularity, of constraint, which makes science possible, somewhere else, even outside the human mind, in social forms, in the relations of production, in the class struggle, etc.

While Chomsky is interested in the "intrinsic capabilities of mind", Foucault is interested in explaining how infinite possibilities of application arise from a limited number of rules which constitute the social conditions of existence.

In insisting on the open nature of the historical system, Foucault's approach to understanding history parallels Derrida's critique and revision of Saussure's in stressing the open and incomplete character of the totality of social relations. In Foucault, however, the analysis proceeds beyond the textual to an analysis of the historical relations between the discursive and pre-discursive, whereas for Derrida and Saussure the analysis is synchronic and confined to language. For Foucault, what is analysed is social practices - both discursive and nondiscursive. Although this establishes a sociological holism and social objectivism which is anterior to the individual human subject, it is not a 'spirit' or 'mind' in the Hegelian (Geist) or Durkheimian (Collective representations or consciousness) sense, but, influenced by the linguistic turn, a series of practices - habits, actions, mores, customs, languages - which function like a language, and from which individuals derive and alter meanings. In this sense, Foucault's sociological objectivism is akin to Wittgenstein' (forms of life), or 
Lévi-Strauss's (symbolic systems), in that objective social reality, while having ontological status, is not posited as a superior mind or intelligence which presides over other (mere ordinary) individual actors in history.

\section{Notes}

${ }^{1}$ In his review of Deleuze's books, ('Theatrum Philosophicum') Foucault (1998: 366) reinforces the importance of chance: "The present as the recurrence of difference, as repitition giving voice to difference, affirms at once the totality of chance. The univocity of being in Duns Scotus led to the immobility of an abstraction, in Spinoza it led to the necessity and eternity of substance; but here it leads to the single throw of chance in the fissure of the present. If being always declares itself in the same way, it is not because being is one but because the totality of chance is affirmed in the single dice throw of the present".

${ }^{2}$ As, for example, when they tried to test Copernicus's theories in astronomy by dropping stones from church spires to test to see whether the earth was rotating on its axis.

${ }^{3}$ See, for instance, Foucault's essay 'Truth and Juridical Forms', originally published in May 1973, where he summarises Spinoza in relation to Nietzsche (Foucault, 2001: 11-12); again, Foucault refers to Spinoza in the debate with Chomsky (Foucault, 1997: 136); in 'Theatrum Philosopicum' (Foucault, 1998: 359 -60 and 36667); and in 'Afterword to The Temptation of St Anthony' (1998: 105), just to name a few. It is also noteworthy that Deleuze was influenced by Spinoza, as Deleuze had a strong influence on Foucault. See Paul Veyne (1997: 63-64), 'Foucault Revolutionizes History' . Also see index entries to Deleuze and Guattari (1987), Deleuze (1990, 1994) and others. Like Deleuze, Foucault (1998: 364) 'adapts' Spinozist concepts to express his views. For example: "The univocity of being, its singleness of expression, is paradoxically the principal condition that permits difference to escape the domination of identity, frees it from the law of the Same as a simple opposition within conceptual elements".

${ }^{4}$ Michael Hardt has already noted the importance of Spinoza's conception of power on Foucault. See 'Translator's Foreword: The Anatomy of Power' in Antonio Negri's The Savage Anomaly: The power of Spinoza's metaphysics and politics (1991). On the theme of complexity, see Damasio (2003).

${ }^{5}$ Foucault, like Nietzsche, wrote philosophically, and hence his use of terms like 'chance', unpredictability' possibly lack technical translatability to the language of natural science. An account of how classical definition of concepts such as 'stability', chance, etc is given by Cilliers (1998). One way to define 'chance' might be to see it as not incompatible with a Newtonian universe. In complex systems, as Cilliers (1998: 109) says, "novel, unpredicted behaviour need not be a result of chance. It can be 'caused' by the complex interaction of a large number of factors.... Complexity is not to be confused with randomness and chance, but cannot be confused with first-order logical terms either". In this sense, we can speak of events which are theoretically unpredictable, which are not explainable in terms of 'chance.'

\footnotetext{
${ }^{6}$ For other accounts of chaos theory, see Swinney (1983), Holden (1985), Gleick (1987), Sappington (1990), Ayers (1997).

${ }^{7}$ Chaos theory and complexity theories are distinct although chaos theory can be seen as one type of complexity theory, which emphasises the importance of sensitivity to initial conditions. This is not so important with complex systems in general, which stresses the interaction of a large number of components (see Cilliers, 1998: ix).

${ }^{8}$ Prigogine mostly applies these ideas to physical systems, but does sometimes demonstrate their applicabliliy to the social and human world. Discussing his theories of time and irreversibility, he notes how all events (e.g., "a marriage is an irreversible event" (2003: 67). The consequence of irreversibility is that "it leads to probabilistic descriptions, which cannot be reduced to individual trajectories or wavefunctions corresponding to Newtonian or Quantum mechanics” (p. 75).
}

\footnotetext{
${ }^{9}$ Meaning is conferred not by one to one correspondence with the world but by relationships between structural components of the system. See Cilliers 1998: 81. His analysis of post-structural complexity is based on Saussure's well-known analysis in the Course in General Linguistics (1974). Having said this, it is interesting that Cilliers translates post-structural philosophy into western analytic schemas rather than elaborate his thesis in relation to difference theory as elaborated by Foucault or Deleuze. I have done the same here simply to convey something of the tenor of the post-structural innovation.

${ }^{10}$ Other forms of emergentist materialism in western thought, see Bunge (1977), Haken (1977, 1990), Rapp et al (1986) or Skarda and Freeman (1990). Although such theories are broadly analogous to Foucault's materialism, the emphasis in post-structuralism on the open and incomplete character of the totality presents new insights into issues like determination and chance. Again, see Cilliers (1998)
} 


\footnotetext{
${ }^{11}$ For another view of complexity theory, see Kauffman $(1991,1993,1995)$. Kauffman suggests that while events can be seen as having antecedent conditions which explain them, in open environments the possible combinations are unpredictable. Other characteristics of complex systems are that they do not operate near equilibrium; the relationships between components are non-linear and dynamic; elements do not have fixed positions; the relationships between elements are not stable; and there are always more possibilities than can be actualised

${ }^{12}$ The notion, for example, that carbon emissions can trigger climate change, which can have potentially unpredictable effects of unimaginable severity, is one illustration of how determination works in relation to complex causality.

${ }^{13}$ For Derrida (1981: 26) the sign has no positive identity but comprises only the collection of traces of all the other signs that run through it.

${ }^{14}$ If we think of someone like 'Churchill', there is something trite as representing him as the outcome of the play of differences (Churchill is not Balfour, not Astor, not Baldwin, etc) for agency in history established a substantial, yet non-essential sense. Yet this identity is still always precarious, incomplete, fragmented, inconsistent, and transitional. It represents at any particular time, a 'settlement'.

${ }^{15}$ Liberals, especially Rawls (1971), bemoaned in A Theory of Justice that it was necessary to retreat to deontology (return to a rights discourse) because social approaches (including utilitarianism) could not account for the distinctness of identity.

${ }^{16}$ Such theories of complex emergentist materialism can also account for the origins of mind as irrepressible (non-reducible) yet wholly material, or physical.

${ }^{17}$ Such complex non-linear models are historically contingent in terms of their internal, substantive arrangements. In Althusser, the variability of the effectivity of the levels of practices of the social formation conforms to such a complex formula, albeit in structuralist and decidedly non-nominalistic terms. The ultimate necessity of the economic however, does not conform, as it introduces a causal factor which is historically invariant across successive modes of production. In this sense, to use Deleuze and Guattari's (1987) language, Althusser's model of structural causality conforms to both rhizonomic and arborescent forms.

${ }^{18}$ Damasio (2003: 45-46) uses examples of social emotions including sympathy, embarrassment, shame, etc., to exemplify the nesting principle. As he states (pp. 45-46): "a whole retinue of regulatory reactions along with elements present in primary emotions can be identified as subcomponents of social emotions in varied combinations. The nested incorporation of components from lower tiers is apparent. Think how the social emotion "contempt" borrows from the facial expressions of "disgust", a primary emotion that evolved in association with the autonomous and beneficial rejection of potentially toxic foods". The appropriate image for these reactions "is not that of a simple linear hierarchy" (p.38).
}

Allison, D. B. (1977) (ed.) The New Nietzsche, New York: A Delta Book.

Ayers, S. (1997). The application of chaos theory to psychology. Theory and Psychology, 7(3), 373-398.

Bateson, G. (1972) Steps Towards an Ecology of Mind. New York: Ballantine Books.

Bunge, M (1977) Emergence and the Mind: Commentary. Neuroscience, 2: 501 - 509.

Cilliers, P. (1998) Complexity and Postmodernism, London and New York: Routledge.

Currie, M. (2004) Difference. London and New York: Routledge.

Damasio, A. (2003) Looking for Spinoza. London: Verso

Davidson, A. (1997). Foucault and His Interlocutors. Chicago \& London: University of Chicago Press.

Deleuze, G. (1985) 'Nomad Thought', in Donald B. Allison (ed.). The New Nietzsche, Cambridge Mass.: MIT Press.

Deleuze, G., and Guartari, F. (1987) A Thousand Plateaus: Capitalism and Schizophrenia. Trans. and Foreword by Brian Massumi. London and New York: Continuum. 
Deleuze, G. (1990) The Logic of Sense, trans. Mark Lester with Charles Stiavale, ed. Constantin V. Bourdas, New York: Columbia University Press.

Deleuze, G. (1994) Difference and Repitition. Trans. Paul Patton, London: Continuum.

Derrida, J. (1981) Positions. Chicago: University of Chicago Press.

Dreyfus, H. (1992) On the ordering of things: Being and power in Heidegger and Foucault. In Timothy J. Armstrong (ed.), Michel Foucault: Philosopher, pp. 80 - 98, New York and London: Harvestor/Wheatsheaf.

Foucault, M. (1970) The Order of Things. New York: Random House.

Foucault, M. (1972). The Archaeology of Knowledge (trans. A. Sheridan). London: Tavistock.

Foucault, M. (1977a) Nietzsche, genealogy, history. In Language, Counter-Memory, Practice: Selected Essays and Interviews (Ed. D.Bouchard) (pp. 139-164). Ithaca,N.Y.: Cornell University Press.

Foucault, M. (1977b). Discipline and Punish (trans. A. Sheridan). New York: Pantheon.

Foucault, M. (1978). Politics and the study of discourse (trans. C. Gordon). Ideology and Consciousness, 3(Spring), 7-26.

Foucault, M. (1980). Truth and power. In C. Gordon (Ed.), Power/Knowledge: Selected Interviews and Other Writings 1972-1977 (pp. 109-133). Brighton: Harvester Press.

Foucault, M. (1980a). Prison talk (trans. C. Gordon). In C. Gordon (Ed.), Power/Knowledge: Selected Interviews and Other Writings, 1972-1977 (pp. 37-54). Brighton: Harvester Press.

Foucault, M. (1981). The order of discourse (trans. Ian McLeod). In R. Young (Ed.), Untying the Text. London: Routledge \& Kegan Paul.

Foucault, M (1984a) 'Preface to the History of Sexuality, Volume II'. In P.Rabinow (ed.), The Foucault Reader. New York: Pantheon.

Foucault, M. (1984b) Polemics, politics, problematizations, trans. L. Davis. In P. Rabinow (ed.), The Foucault Reader, pp 381-389. New York: Pantheon.

Foucault, M. (1985) Final interview, trans. T. Levin and I. Lorenz, Raritan, 5 (Summer), 1-13 (interview conducted by G. Barbedette, published in Les Louvelles, June 28, 1984.

Foucault, M. (1987). Questions of method. In K. Baynes, J. Bonman \& T. McCarthy (Eds), After Philosophy, End or Transformation. Cambridge, Mass.: MIT Press.

Foucault, M. (1990) Maurice Blanchot: The Thought from Outside', in Michel Foucault and Maurice Blanchot, Foucault/Blanchot, Trans. Jeffrey Mehlman and Brian Massumi, New York: Zone Books. 
Foucault, M. (1994a). La philosophie analytique de la politique. In D. Defert \& F. Ewald (Eds) with J.

Lagrange, Dits et écrits, 1954-1988, 4 Vols (Vol. 3, No. 232, pp. 534-551). Paris: Éditions Gallimard.

Foucault, M. (1994b). Linguistique et sciences sociales. In D. Defert \& F. Ewald (Eds) with J. Lagrange, Dits et écrits: 1954-1988, 4 Vols (Vol. 1, No. 70, pp. 821-842). Paris: Éditions Gallimard.

Foucault, M. (1998) ‘Theatrum Philosophicum'. In James D. Faubion (ed.) Michel Foucault: Aesthetics, Method, and Epistemology (the essential works, volume 2) Allen Lane: The Penguin Press, pp.343 368.

Foucault, M. (1998a) Afterword to The Temptation of Saint Anthony. In James D. Faubion (ed.) Michel Foucault: Aesthetics, Method, and Epistemology (the essential works, volume 2) Allen Lane: The Penguin Press, pp.103-123.

Foucault, M. (2001) Interview with Michel Foucault', in James D. Faubion (ed.) Michel Foucault: Power (the essential works, volume 3) Allen Lane: The Penguin Press, pp. 239-297.

Frank, M. (1992) On Foucault's concept of discourse, in Timothy J. Armstrong (ed.), Michel Foucault: Philosopher. New York: Harvestor/Wheatsheaf.

Foucault, M., and Chomsky, N., (1997) Human Nature: Justice vs. power. In A. I. Davidson (ed.), Foucault and His Interlocutors. Chicago and London: University of Chicago Press.

Gleick, J. (1987) Chaos: Making a New Science. London: Abacus.

Haken, H. (1977). Synergetics - An introduction. Springer Series of Synergetics, 1. Berlin: Springer.

Haken, H. (1990). Synergetics as a tool for the conceptualization and mathematization of cognition and behaviour - How far can we go? In H. Haken \& M. Stadler (Eds), Synergetics of Cognition (pp. 2-31). Berlin: Springer.

Heidegger, M. (1991) Nietzsche, (two volumes) trans., David Farrel Krell. San Francisco: Harper Collins.

Holden, A. (1985). Chaos is no longer a dirty word. New Scientist, 12-15, 25 April.

Kauffman, S. A. (1991) ‘Antichaos and adaptation’, Scientific American. August, pp. 64-70.

Kauffman, S. A. (1993) The Origins of Order: Self-Organisation and Selection in Evolution. New York: Oxford University Press.

Kauffman, S. A. (1995) At Home in the Universe; The Search for Laws of Complexity. London: Viking Press. Margolis, J. (1993). The Flux of History and the Flux of Science. Berkeley: University of California Press. Nietzsche, F. (1967) On the Genealogy of Morals. Ecce Homo. Trans. Walter Kaufmann. New York: Random House. 
Nietzsche, F. (1968) The Will to Power. Ed. Walter Kaufmann, Trans. Walter Kaufman and R.J.Hollingdale. New York: Vintage Books.

Negri, A. (1991) The Savage Anomaly: The power of Spinoza's metaphysics and politics. Trans. Michael Hardt. Minneapolis: University of Minnesota Press.

Olssen, M. (1999) Michel Foucault: Materialism and Education. Westport: Bergin and Garvey.

Olssen, M. (2006) Michel Foucault: Materialism and Education. Boulder/London: Paradigm Press.

Prigogine, I. (1980) From Being to Becoming, San Francisco: W.H.Freeman and Company.

Prigogne, I., and Stengers, I. (1984) Order Out of Chaos. New York: Bantam.

Prigogine, I. and Nicolis, G. (1989) Exploring Complexity. New York: W .H. Freeman.

Prigogine, I. (1994) Time, Chaos and the Laws of Chaos. Moscow: Ed. Progress.

Prigogne, I. (1997) The End of Certainty: Time, chaos and the new laws of nature. New York: The Free Press. Prigogine, I. (2003) Is Future Given. New Jersey: World Scientific.

Rapp, P.E., Zimmerman, I.D., Albano, A.M., de Gusman, G.C, Grenbauri, M.N. \& Bashmore, T.R. (1986). Experimental studies of chaotic neural behaviour: Cellular activity and electronencephalographic signals. In H.G. Othmer (Ed.), Nonlinear Oscillations in Biology and Chemistry. Berlin: Springer.

Rawls, J. (1971) A Theory of Justice, Oxford: Oxford University Press.

Sappington, A.A. (1990). Recent psychological approaches to the free will versus determinism issue.

Psychological Bulletin, 108, 19-29.

Sardar, Z. and Abrams, I. (1999) Introduciing Chaos. Cambridge: Icon Books Ltd.

Saussure, F. de (1974) Course in General Linguistics. London: Fontana.

Schrift, A.D. (1995) Nietzsche's French Legacy: A Genealogy of Poststructuralism. New York, London: Routledge.

Skarda, C.A. and Freeman, W.J. (1990) Chaos and the new science of the brain, Concepts in Neuroscience, 1, $275-285$.

Swinney, H.L. (1983) Observations of order and chaos in non-linear systems. Physica, 7, 3-15.

Veyne, P. (1997) 'Foucault Revolutionizes History’, in Arnold Davidson (ed.) Foucault and His Interlocutors. Chicago \& London: University of Chicago Press. 


\begin{abstract}
:
This article explores the affinities and parallels between Foucault's Nietzschean view of history and models of complexity developed in the physical sciences in the twentieth century. It claims that Foucault's own rejection of structuralism and Marxism can be explained as a consequence of his own approach which posits a radical ontology whereby the conception of the totality or whole is reconfigured as an always open, relatively borderless system of infinite interconnections, possibilities and developments. His rejection of Hegelianism, as well as other enlightenment philosophies can be understood at one level as a direct response to his rejection of the mechanical atomist, and organicist epistemological world views, based upon a Newtonian conception of a closed universe which operated upon the basis of a small number of invariable and universal laws, by which all could be predicted and explained. The idea of a fully determined, closed, universe is replaced; and in a way parallel to complexity theories, Foucault's own approach emphasises notions such as selforganisation and dissipative structures; time as an irreversible, existential dimension; a world of finite resources but with an infinity of possibilities for articulation, or re-investment; and characterised by the principles of openness, indeterminism, unpredictability, and uncertainty. The implications of Foucault's type of approach are then explored in relation to identity, creativity, and the uniqueness of the person. We will see that within a complexity theory approach many of the old conundrums concerning determinism and creativity, social constructionism and uniqueness, are overcome.
\end{abstract}

\title{
Keywords:
}

Nietzsche, Heidegger, Marxism, Structuralism, science, complexity theory, llya Prigogine, predictability, uncertainty, identity, uniqueness, creativity

\section{Corresponding author details:}

Mark Olssen is Professor of Political Theory and Education Policy in the Department of Political, International and Policy Studies, School of Arts, University of Surrey, Stag Hill, Guildford GU2 7XH, ENGLAND. Telephone: +44 (0) 1483- 682120; Fax: +44 (0)1483- 686208; webpage:

http://www.surrey.ac.uk/politics/profiles/olssen.htm 